\title{
Clio
}

Women, Gender, History

$40 \mid 2014$

Making Gender with Things

\section{Child's Play? Colonial commodities, ephemera, and the construction of the greater French family}

Apprendre l'Empire, un jeu d'enfants?

\section{Elizabeth Heath}

\section{(2) OpenEdition}

Journals

\section{Electronic version}

URL: http://journals.openedition.org/cliowgh/658

DOI: 10.4000/cliowgh.658

ISSN: 2554-3822

Publisher

Belin

\section{Electronic reference}

Elizabeth Heath, "Child's Play? Colonial commodities, ephemera, and the construction of the greater French family », Clio [Online], 40 | 2014, Online since 15 April 2015, connection on 19 April 2019. URL http://journals.openedition.org/cliowgh/658; DOI : 10.4000/cliowgh.658 


\section{Child's Play? Colonial commodities, ephemera, and the construction of the greater French family}

Eager to promote the Empire, the French Ministry of the Colonies undertook a massive publicity campaign in the 1920s and 1930s. The most spectacular of these endeavors, the 1931 Colonial Exposition, popularized the colonial idea through an elaborate fair showcasing "native" peoples and cultures. ${ }^{1}$ Other forms of publicity more subtly appealed to French metropolitans. A series of posters from the 1930s, for example, educated French consumers, especially mothers, about the importance of colonial goods like chocolate, tea, and bananas. Drawing on modern marketing techniques and ideas of homemaking, the Ministry's chocolate poster intertwined text and image to encourage mothers to spend their limited resources on this colonial good. (fig. 1) The central text reminded viewers that cacao was "one of the primary products of the French Colonies." [l'un des principaux produits des colonies françaises"] A visual narrative traced the process by which natives transformed cacao pods into beans that Europeans and European technology turned into edible delights. The narrative ended with a breakfast scene in which a modern - but not too modern - mother lovingly poured her son a bol of hot chocolate. Through words and pictures, the poster encouraged French women to consider national and imperial concerns alongside family needs. "By eating chocolate, but by eating it in moderation" the poster enjoined, "you will digest a powerful fortifying food and, at the same time, contribute to the development of France's magnificent colonial empire." [En mangeant du chocolat, avec modération... vous

1 Hodeir \& Pierre 1991; Morton 2000. 
absorberez un puissant reconstituant et vous contribuerez en même temps à la mise en valeur du magnifique empire colonial français."]

Ostensibly about chocolate consumption, the Ministry's poster revealed the wide range of concerns driving interwar colonial policy and publicity. The most obvious goal was to promote chocolate consumption and colonial economies in an era of trimmed budgets. ${ }^{2}$ In depicting chocolate as a highly nutritious food, the poster melded notions of personal health, good taste, and national prosperity. ${ }^{3}$ However, the French state had more than economic concerns in mind. The poster also tried to define modern motherhood, depicting the interwar ideal as a blend of older domestic virtues improved by science, industry, and empire. Amidst fears of de-feminized women, depopulation, and racial mixing, the poster delineated French gender norms and colonial racial hierarchies by situating the French family within a wider, colonial family. At the heart of this new imperial order was the cacao tree, which provided products that nourished the French family and sustained the French nation and imperial network.

Through a fantastical representation of chocolate production that erased the coercive elements of imperial rule, the Ministry's poster attempted to create a set of mental associations that linked chocolate and chocolate consumption to idealized notions of the French family. Following this imaginary commodity chain attunes the modern viewer to the role played by colonial materials - whether "embodied material culture" like raw foodstuffs, the products made from them, or the ephemera that marketed and sold them - in shaping key elements of metropolitan life. ${ }^{4}$ Drawing on this poster's explicit efforts to encode chocolate and chocolate consumption, this article explores how material culture opens new ways of understanding how empire shaped normative conceptions of the French interwar family. It does so by focusing on colonial ephemera associated with French colonial cacao and considering how these objects helped constitute metropolitan children as gendered and imperial beings who embraced their future roles within the French nation and empire. By engaging

2 Groff 1987.

3 Frost 1993.

4 Dietler 2007. 
the child consumer in a set of actions and imaginings, and inviting them to fantasize about colonial exploits and life, these objects provided a colonial education. Colonial ephemera brought empire into the home, helping to code everyday actions and place these actions within an imperial order built on gender and racial distinctions. Material culture thus offers the possibility of delving into the imaginaries of metropolitan boys and girls as they practiced, adopted, and interpreted their future roles as metropolitan men and women within the wider French Empire, la plus grande France, and provides a new way to examine the role that empire played in shaping gender in interwar France.

\section{Selling colonial chocolate to French children}

Children were critical to the French Colonial Ministry's interwar project to promote colonial crops such as cacao and valorize the imperial order. This initiative was born of World War I, which profoundly affected metropolitan society and its relationship to the colonies. During the war, colonial troops and workers played an essential role in protecting and defending France. ${ }^{5}$ After the armistice, the Empire's importance grew as the Third Republic drew on colonial populations to counteract demographic decline and massive war casualties. Anxious to bolster the national economy, the French government also worked to make the Empire productive and valuable to metropolitan consumers and industries. Food products were essential to this endeavor. Colonial agents encouraged the production of basic food crops, like rice, tapioca and cassava, and lobbyists discussed ways to supplement essentials of the French diet, like wheat, with colonial products like rice and manioc. ${ }^{6}$ The Ministry also joined forces with colonial producers, commercial agents, and professional groups in order to increase popular consumption of coffee, tea, chocolate, and bananas. Metropolitan French men and women rejected many of these "exotic" foodstuffs, refusing to ingest

5 Fogarty 2008; Stovall 2003.

6 Peters 2004. 
and absorb them into the individual, and national, body. ${ }^{7} \mathrm{~A}$ small subset of products like chocolate, though, had long been available to metropolitan consumers; by the early twentieth century these items regularly served as complements to the French diet, though had not quite been accepted as true "French" food. ${ }^{8}$ Official attempts to increase metropolitan consumption sought to integrate these products more fully into the culinary habits of French metropolitans.

Whether in the form of mass-produced chocolate bars or hot cacao mix, cacao was of particular importance to the Colonial Ministry in the interwar period. Having assumed the mandate for cacao-producing Cameroon, the state sought to capitalize on the benefits of this responsibility. The Ministry had also undertaken a major campaign to promote cacao production in the Ivory Coast just prior to World War I, that it wished to see rewarded. However, in the 1920s and 1930s, expanding production worldwide led to a major collapse of the global cacao market. The Ministry aimed to counter the crisis and salvage both cacao-dependent colonial economies and the metropolitan chocolate industry. This initiative accelerated in the late 1930s. In August 1938, the Ministry created the Comité de propagande pour les cacaos d'origine coloniale française, which was funded by a special tax levied on cacao. The committee's members included cacao producers, cacao importers, and metropolitan industrial chocolate makers. The committee's budget enabled the ministry to advertise in Parisian and regional newspapers, publicize at fairs and exhibitions, purchase radio advertisements, and even to create documentaries for schools, all envisioned as part of a larger project to boost chocolate sales and advance the colonial project. ${ }^{9}$ The Colonial Ministry's cacao poster may have been produced during this publicity campaign and, along with similar posters advertising tea and bananas, it may well have been showcased at local fairs and colonial exhibits (fig. 1). It is, however, difficult to know where exactly where these posters were displayed and the reception they received. Other forms

7 Peters 2004; Janes 2013.

8 Terrio 2000. Also Goody 1982.

9 Ministerial efforts to boost French consumption of chocolate, tea, bananas, and rice can be found in ANOM AGEFOM//5 and ANOM 100APOM/398. 
of publicity, like advertisements published in Paris-Soir, provide a clearer sense of distribution and audience, though again it remains difficult to know whether a reader noticed or was swayed by the publicity.

The committee's goal was to "reach a wide body of consumers" and, in particular, "awaken in the child a taste for chocolate" which, in their estimation, would "attract the attention of parents and above all mothers of families to this colonial product." [d'atteindre une masse très importante de consommateurs"... "d'éveiller chez l'enfant le goût du chocolat"... "attirer l'attention des parents et surtout des mères de famille sur ce produit national."] Children were so essential that the committee even considered making chocolate part of the daily school snack. The committee's long-term goal was nothing less than to "implant the imperial notion in the French soul." In the short term, members wished to boost chocolate consumption and inform the public that chocolate and cacao powder were derived from cacao produced in the French colonies. Advertisements like the chocolate poster, which depicted the commodity chain in sanitized and abbreviated form, reflected this desire to expose the process by which colonial cacao became metropolitan consumer goods. ${ }^{10}$

Privately produced marketing materials supplemented the Ministry's official propaganda. Chocolate manufacturers were as eager as the French state to encourage mass consumption of cacaoderived goods and all the major industrial chocolate producers produced a wide array of promotional materials to win consumers. ${ }^{11}$ Advertising cards, posters, games, paper toys, stickers, and sticker books accompanied products as they left the factory and entered the home. Not all the material produced by commercial manufacturers referenced the colonies, though a considerable percentage drew upon this theme to promote chocolate consumption. Companies created some colonially-themed material for adults, especially women, but focused on children. These promotional materials drew children into

10 Expose des motifs, Budget de propagande du cacao, année 1939. ANOM AGEFOM//5.

11 ANOM AGEFOM//5. 
a larger consumer and imperial culture and educated them about their future roles as white metropolitan men and women.

It is unsurprising that manufacturers and state officials targeted French children. Children were at the center of interwar debates about depopulation and the future of the French family arising from changing gender relations. Whether la garconne, unfeminine wear, or brash attitudes, French officials worried about the modern woman's supposed disregard for the nation's future. ${ }^{12}$ The jazz age, with its purported promotion of racial mixing and social disorder, compounded such anxieties. These fears all expressed a deeper concern about the future of French "civilization."13 In this context, children acquired a new value. Moreover, nearly all agreed that childhood constituted a key moment of socialization; the state thus looked at children as future parents, while marketers regarded them as future consumers. To win over children both produced materials that entertained and educated.

At first glance, many of these promotional materials do not seem particularly noteworthy. Most were ephemera (figs 2, 3, 4). Games and toys were made of thin paper to be used until ragged, torn, or faded. Advertising cards and book covers proved more durable, but still disposable. The fleeting quality of the materials meant that adults were likely to accord them little value. Children, of course, might have interpreted the objects differently - perhaps seeing them as special treasures - but they too eventually encountered their material limits. The most significant and lasting objects were likely the sticker books, which children purchased by mail and which represented an investment of time and money.

The objects are visually striking, and historians have analyzed similar materials as reflections of French racial thinking. ${ }^{14}$ It is notable that this particular set of chocolate ephemera displayed little of the modern style characteristic of the 1920s and 1930s found in

\footnotetext{
12 Roberts 1994.

13 Berliner 2002.

14 Garrigues 1991; Bachollet 1992; Nederveen-Pieterse 1992; Bancel, Blanchard \& Delabarre 1993; Bancel, Blanchard \& Gervereau 1993; Archer-Straw 2000; Hale 2008.
} 
other interwar advertising. ${ }^{15}$ In contrast, the objects recall pre-war marketing images, suggesting an attempt to recapture the innocence of an earlier time when gender and family structures seemed less contentious. Advertisers may have also chosen this antiquated look in order to remind consumers that chocolate had long been part of the French homes and diet. Looking at these materials as objects to be used by children, however, suggests they played a more radical role. These were not images to be glanced at fleetingly, but materials that attempted to engage children in concrete actions and prepare them to assume the role of soldier, explorer, commercial agent, mother, household manager, and, of course, chocolate consumer. Seen this way, it becomes clear that these objects were not simply nostalgic expressions for an idealized pre-war order or a clever marketing ploy, but active elements in the construction of an interwar culture that envisioned the French family as the nexus of an imperial network.

\section{Games, playthings, and imperial imaginaries}

Three examples found in the Getty Research Institute's Association "Connaissance de l'histoire de l'Afrique contemporaine" collection are representative of the genre of colonial ephemera: the sticker book; the paper diorama; and the game. Children engaged with the objects in a number of ways: collecting and organizing stickers and cards; cutting out and arranging figures; and exchanging and trading materials in a board game. Each object enticed the child into a set of concrete actions that paralleled the colonial project and invited the child to imagine the Empire and his or her place within it, thereby bringing the Empire into everyday consciousness. This fantasy world was not mere child's play to be discarded with age, however, but the foundation of a new imperial order. It was, as Jacqueline Rose has argued, "not antagonistic to social reality" but rather "its precondition or psychic glue," something that "plays a central constitutive role in the modern world of states and nations." 16 By inviting the child to participate in an imaginary of French colonialism, the pieces aimed to

\footnotetext{
15 Thank you to the anonymous reader for pointing this out.

16 Rose 1996: 3.
} 
generate a repertoire of actions and thoughts that would naturalize normative concepts about race, gender, and the imperial order as well as create future consumers.

The earliest of these products is the sticker book issued by the Swiss-based chocolate company Cémoi in the 1930s (fig. 2). Though a Swiss company founded in Grenoble in 1919, Cémoi purchased some of its cacao from the French colonies. Swiss chocolate makers used this fact to their advantage. ${ }^{17}$ Léon Gittard, the director of the Genevabased Office de propagande et de vente pour la Suisse des produits coloniaux français, in fact, even asked the French Minister of the Colonies to include the group in the Cacao Committee, noting that the organization worked to encourage Swiss purchases of French colonial cacao. ${ }^{18}$ Playing to the French Ministry's interests made good sense for a company like Cémoi, which recognized that advertising the French origins of its chocolate was a way to boost sales in a prime market.

Made of durable paper and hard covers, Cémoi's sticker book was meant to last. As the stickers were found only in chocolate bars and the album purchased by mail, the book required a child's - or family's money and dedication. Once stickers and book were united, the child had to paste the stickers to complete the book's narrative about French Equatorial Africa, its peoples, and resources. The process of collecting, saving, sorting, classifying, and pairing stickers with the empire's different regions, peoples, and resources was meaningful work that replicated the mechanics of colonial administration.

Exchange played a central theme in the Cémoi album. The book's cover depicts two metropolitan French children astride an ostrich, offering a chocolate bar and hot cocoa mix to an ebullient African family. The nature of this exchange is not clear. Are the children offering the chocolate as a gift? Or is this a commercial exchange, in which the children are returning the final product to the cacao producers to sell it at the Dépôt Do-Fi-Ney? The lines between gift

17 The original Cémoi was purchased in 1981 by a French company CantaloupCatala, which took over the Cémoi name. www.cemoi.fr.

18 Letter, Léon Gittard to Maurice Besson, Director, Agence Économique du Gouvernement Général de l’Afrique Occidentale Française, 26 September 1938. ANOM AGEFOM//5 
giving, payment, and trade are blurred, but one fact is clear: this is an exchange that reinforces and strengthens the social and economic ties linking these two families.

Though as the cover illustrates, this was a social relationship with obvious hierarchies. The image itself, which foregrounds the metropolitan children, presumably brother and sister, who sit atop a domesticated African animal and tower over the African family, illustrates the unequal nature of this relationship. However, it is the objects that the children hold that define their elevated status within a colonial order. The pair carry finished chocolate products, dress in fashionable clothing, and are equipped with satchels to store their wares. The boy even wears a pith helmet, the quintessential icon of colonial authority. In contrast the African family possesses little apart from their clothes and hut. Even at their young age the brother and sister assume a parental role, caring and providing for the colonial family.

This family, however, is built on clear racial and gender distinctions. The boy and girl constitute a small couple united by a common goal of providing chocolate to the African family. That they are only accompanied by an ostrich and without any "real" parental guidance suggests the fantasy in which they - and all other metropolitan children - are engaged is a family romance in which they imagine themselves the legitimate head of an imperial family. ${ }^{19}$ There are subtle differences between the boy and girl that mark appropriate gender norms. Whereas the boy is sitting high upon the ostrich and confidently offering the chocolate bars, the girl only holds the canister of hot chocolate breakfast mix. Among the African family - who are rendered small and childlike - it is the father and boys that greet the children, though they do so with flailing arms, marking a contrast between these two forms of masculine power.

The stickers within the album reinforce these gender distinctions, again through associations with material goods. The stickers depict the distinctive culture of a handful of African tribes, the colonies'

19 This is a modified version of Freud's idea of the family romance in which children fantasize that they are the children of different parents, usually of a higher social status. Here the children imagine themselves as the better parents of an imperial family whose "children" consist of colonial subjects. Freud 1990. 
productive capacities, flora and fauna. Men are shown to be "productive", at least in the sense of providing resources to metropolitan consumers. The stickers depict "native" men as woodcutters, crocodile-, lion-, and ivory-hunters, cacao plantation workers, and weavers among other occupations. Women, in contrast, are associated with elaborate hairstyles, childcare, and "primitive" homemaking - all forms of work, but ones that did not immediately generate colonial material or wealth. Thus within the album, material objects and forms of labor distinguish the population, code their actions, and establish appropriate social, gender, and racial hierarchies.

Conceptions of work, and notions of colonial femininity are developed further by the paper diorama produced by Cacao Barry in the 1930s (fig. 3). Founded in 1842, and known for its chocolate baking sticks, Cacao Barry was one of France's major producers of chocolate in the interwar period. The advertisement they chose for the period was a kind of colonial ethnographic scene aimed at young girls. The diorama required young girls (or their mothers) to cut out the figures, already a practice of care. Once cut out, the pieces could be ordered by the girl according to codes, thereby creating a static panorama of colonial life. Through this configuration, young girls learned to order the colonial household and, presumably compare it to her own home. It is notable that the Cacao Barry diorama blurs the lines between home and market, showing the father-less family as working to harvest and process cacao just outside their strawthatched hut, a family scene that likely differed considerably from the child consumer's own family.

As a static picture, the diorama required the young girl to imagine the small family's world. The diorama, like the poster, offers a fantastical image of colonial production. The proximity of the family's hut and cacao tree and the family's smiling faces suggest that cacao production was a cottage industry, something that the mother perhaps took on to provide the family with extra income while the father was away at his day job. The reality, of course, was quite different. While smallholders produced cacao in colonies like the Ivory Coast, this cultivation was not entirely by choice, but forced by 
the French colonial state in 1912 and 1913. ${ }^{20}$ Meanwhile, French colonial labor policies required local men to leave their families for weeks at a time in order to work on public works and larger plantations. However, for a metropolitan girl conditioned to the idea that all fathers worked outside the home and served as the primary breadwinner, this absence may have appeared unremarkable. Instead, it reinforced the idea that the mother and children's work was supplemental, assumed by the colonial mother to improve the family's fortunes. Through this scene, the diorama may have created a sense of solidarity, suggesting to the girl that she bore a certain responsibility to this imaginary family whom she so carefully cut out and arranged in their proper order. She could continue to help the imagined African family by purchasing and consuming the products they produced. As the consumer, the young metropolitan girl became a kind of benefactor. The diorama thus intertwined race, class, and gender to encourage the girl to see chocolate consumption as a feminine duty.

In contrast, imperial masculinity was not to be found in consuming colonial goods, but working to ensure the Empire could produce these goods for metropolitan populations. The "Jeu des échanges France-Colonies" is, at first touch, unremarkable (fig. 4). Made of thin linen, the board and its pieces likely had a short life. Produced in 1941 by the Office de publicité et d'impression, this official piece of propaganda belies the turbulence of the Vichy regime. Rather the game projects a sense of normalcy, suggesting that the Empire was again a stabilizing influence, one that promised to preserve French life and norms despite the upheavals of the war. Under the shadow of the defeat, French boys could still imagine a world where they could assert their authority and power and serve the nation and make it prosper.

The game was relatively straightforward: each player developed "his" colonies and exported products to the metropole. The first to complete this task, and dispose of all tokens, won. Like in real life, colonial development took time and patience. Each player had to acquire flags and ships and trade with others for development pieces.

20 Groff 1987. 
Although the game focused on trade, the rules emphasized that colonial development meant more than economic exploitation. Before a colony could be considered settled, the player had to play a flag piece associated with hospitals, schools, missions and other modernizing infrastructure. Only after a colony had been "civilized" and productivized could it be considered truly "developed." As in colonialism itself, progress was rife with hazards. Laziness, disease, and intemperance - three of the corner squares that squandered time and tokens - were qualities that threatened the colonial project. In contrast, skill, frugality, science and cultivation - in short the characteristics of enlightened, rational bourgeois civility - led to success.

By inviting French youth to claim, build, and exploit rationally the colonies, the game not only encouraged players to fantasize about the French colonial mission but, in fact, required them to act out the process of imperial expansion and educated them about the mechanics of colonial rule. At its core, the game suggested that colonialism constituted a set of exchanges between peoples; France provided infrastructure, modern institutions, and economic development, in return for raw materials and exotic wares. The game explicitly highlighted the empire's resources, whether exotic goods like monkeys or modern essentials like coffee, chocolate, and rubber. As such, the game educated players about the origins of the goods that populated their home and tables, and offered a glimpse of the structures that sustained this exchange. In imagining himself as a colonial official, the child learned how to maintain the empire, amass national wealth, and also guard against "colonial" problems like laziness or sick "natives." In short, the game trained young players to assume the role of colonial administrator.

The game clearly marked colonialism as a man's work. Even though the rules made no reference to the players' sex, all depicted - the white colonial officers, "native" servants, and "native" workers - were men, thus coding the player's actions as masculine. By depicting trade, development, and exchange as explicitly masculine endeavors, the game gendered colonial activities. The colonial officer's role was to ensure development while guarding against excesses - like intemperance and laziness - associated with the colonial space. In each case, "natives" aided these forms of moral 
laxity. The game thus established a clear hierarchy between true "white" masculinity, which was concerned with development, civilization, and rational economic exploitation, and "indigenous" behavior that weakened metropolitan resolve. Throughout the game, players learned to adopt behaviors - and social and racial hierarchies - that ensured a prosperous and productive Empire that would help France weather the war.

The objects analyzed in this article point to the fact that the interwar French family was a colonial family; gender, gender roles, and gender norms were learned and practiced in an imperial context and against a colonial double. Colonial ephemera brought the empire into the home and nursery, naturalizing the empire. Moreover, ephemera helped define everyday actions and activities as gendered and meaningful to the maintenance and prosperity of the imperial family. This family was, of course, defined by difference; chocolate ephemera made these social relationships and hierarchies explicit. Through their use, boys and girls learned to act as metropolitan men and women.

Historians have long debated the importance of empire to metropolitan populations. Material culture opens new ways for historians to reconsider this central question. When analyzed as constitutive elements of an imperial social order rather than reflections of popular interest and enthusiasm, material culture offers an exit from an earlier debate that pitted "minimalists", who argued that empire was relatively unimportant to metropolitans, against "maximalists" who claimed that empire played a fundamental role in metropolitan life, an idea bolstered by the ubiquity of imperial displays, propaganda, expositions, and other popular expressions of colonial support. ${ }^{21}$ Material culture provides historians a way to move away from questions of interest and affect and to explore how empire

21 On the British Empire: Porter 2006; MacKenzie 1986; Thompson 2005. On the French Empire: Girardet 1972; Schneider 1982; Bancel, Blanchard \& Gervereau 1993; Bancel, Blanchard \& Delabarre 1997; Chafer \& Sackur 2002. On commodity culture, imperial propaganda, and race: Nederveen-Pieterse 1992; Bachollet 1992; McClintock 1995; Archer-Straw 2000; Ciarlo 2011. 
helped constitute metropolitan social structures and norms on an everyday and almost unconscious level.

Colonial objects like the sticker book, diorama, game, and poster drew users - in this case children - into a wider social network that linked colonial producers with metropolitan consumers. Like all material objects, these playthings were "active agents" that invited, even compelled, children to use them in particular ways. Moreover, these objects ascribed social meaning to these activities and, in the process, helped generate normative concepts like masculinity and femininity. ${ }^{22}$ Examining these sources thus offers the possibility of delving into the imaginaries of metropolitan boys and girls as they practiced and adopted their future roles in la plus grande France and embraced the racial and gendered categories that sustained the French imperial nation-state. These structures of thought, first formed through fantastical imaginings and playacting, served as the cognitive foundation of an imperial identity with roles for metropolitan men and women and their colonial doubles. Colonialism, it becomes clear, was central to ideas about gender, masculinity, femininity, and other basic social categories that ordered the French imperial nation in the interwar period.

Analyzed from this perspective, material objects and the actions they generate can provide access into the processes by which human actions, experiences, emotions, ideas and perceptions assume social meaning and importance. Objects thereby offer insights into the processes by which "difference is established, how it operates, how and in what ways it constitutes subjects who see and act in the world," a key concern of gender historians and new imperial historians alike. ${ }^{23}$ By embracing material culture as a source base, gender historians will find new avenues for exploring the complex ways that empire and race shaped metropolitan conceptions of gender, family, and the nation. ${ }^{24}$ Being imperial and being French, it becomes clear, were not so easily disentangled. Rather, colonialism

22 Appadurai 1986; Auslander 2005; Miller 2010. On the issue of gender and meaning see Rosaldo 1980: 400. Also Scott 1986; Scott 1991; Canning 2006.

23 Scott 1991: 777-778; Wilson 2004: 3; Cooper 2005: 26.

24 As exemplified by Gouda \& Clancy-Smith 1998; Levine 2003; Hall \& Rose 2006. 
- and colonial products and marketing material- served as constitutive elements of what it meant to be French. These ideas were, of course, not without dispute and would be contested throughout the interwar and post-World War II period. At their core, these struggles were not just fights about the colonial political and economic order, but attempts to define and preserve an entire cognitive structure and way of understanding Frenchness.

\section{Bibliography}

ACHAC. 1993. Images et colonies: nature, discours et influence de liconographie coloniale liée à la propagande coloniale et à la représentation des Africains et de l'Afrique en France, de 1920 aux indépendances: actes du colloque organisé par l'ACHAC du 20 au 22 janvier 1993 à la Bibliothèque nationale. Paris: Syros.

Archer-Straw, Petrine. 2000. Negrophilia: avant-garde Paris and black culture in the 1920s. London: Thames \& Hudson.

Appadurai, Arjun (ed.) 1986. The Social Life of Things: commodities in cultural perspective. Cambridge: Cambridge University Press.

Auslander, Leora. 2005. Beyond words. American Historical Review 100(4): 1015-1045.

BACHOLLET, Raymond. 1992. Négripub. L'image des noirs dans la publicité. Paris: Somogy.

Bancel, Nicholas, Blanchard, Pascal, and Francis Delabarre. 1993. Images d'empire: 1930-1960, trente ans de photographies officielles sur l'Afrique francaise. Paris: Éditions de la Martinière.

Bancel, Nicholas, Blanchard, Pascal, and Laurent Gervereau. 1993. Images et colonies : iconographie et propagande coloniale sur l'Afrique française de 1880 à 1962. Paris: ACHAC.

Berliner, Brett. 2002. Ambivalent desire: the exotic black other in jazi-age France. Amherst: University of Massachusetts Press.

Canning, Kathleen. 2006. Gender History in Practice: historical perspectives on bodies, class \& citizenship. Ithaca: Cornell University Press.

ChAFer, Tony, and Amanda SACKuR, eds. 2002. Promoting the Colonial Idea: propaganda and visions of Empire in France. New York: Palgrave.

Ciarlo, David. 2011. Advertising Empire: race and visual culture in imperial Germany. Cambridge: Harvard University Press.

COOPER, Frederick. 2005. Colonialism in Question: theory, knowledge, history. Berkeley: University of California Press. 
DieTLER, Michael. 2007. Culinary encounters: food, identity, and colonialism. In Archeology of Food and Identity, ed. Katheryn Twiss, 218-242. Carbondale: Southern Illinois University Press.

FOGARTY, Richard. 2008. Race and War in France: colonial subjects in the French army, 1914-1918. Baltimore: Johns Hopkins University Press.

Freud, Sigmund. 1990. The Standard Edition of the Complete Psychological Works of Sigmund Freud, Vol. 9. New York: Norton.

Frost, Robert. 1993. Machine liberation: investing housewives and home appliances in interwar France. French Historical Studies 18(1): 109-130.

Garrigues, Jean. 1991. Banania. Histoire d'une passion française. Paris: Du May.

GoudA, Frances \& Julia Clancy-Smith (eds) 1998. Domesticating the Empire: race, gender and family life in French and Dutch colonialism. Charlottesville: University Press of Virginia.

GirARDET, Raoul. 1972. L'Idée coloniale en France de 1871 à 1962. Paris: Table Ronde.

GoOdy, Jack. 1982. Cooking, Cuisine, and Class: a study in comparative sociology. Cambridge: Cambridge University Press.

GrofF, David.1987. Carrots, sticks, and cocoa pods: African and administrative initiatives in the spread of cocoa cultivation, Assikasso, Ivory Coast, 1908-1920. International Journal of African Historical Studies 20(3): 401-416.

Hale, Dana. 2008. Races on Display. Bloomington: Indiana University Press.

Hall, Catherine \& Sonya Rose (eds) 2006. At Home with the Empire: metropolitan culture and the imperial world. Cambridge: Cambridge University Press.

HodeIr, Catherine \& Michel PIERrE. 1991. L'Exposition coloniale : 1931. Bruxelles: Éditions Complexe.

JANES, Lauren. 2013. Selling rice to wheat eaters: the colonial lobby and the promotion of pain de riz during and after the First World War. Contemporary French Civilization 38(2): 179-200.

KAPLAN, Cora. 2006. Imagining Empire: history, fantasy, and literature. In At Home with the Empire: metropolitan culture and the imperial world, ed. Catherine HALL and Sonya Rose, 191-211. Cambridge: Cambridge University Press.

Levine, Philippa. 2003. Prostitution, Race, and Politics: policing venereal disease in the British Empire. New York: Routledge.

MackenzIE, John (ed.) 1986. Imperialism and Popular Culture. Manchester: Manchester University Press.

MCCLINTOCK, Anne. 1995. Imperial Leather: race, gender, and sexuality in the colonial contest. New York: Routledge. 
MiLler, Daniel. 2010. Stuff. Cambridge: Polity.

MORTON, Patricia. Hybrid Modernities: architecture and representation at the 1931 Colonial Exposition, Paris. Cambridge: The MIT Press.

Nederveen-Pieterse, Jan. 1992. White on Black: images of Africa and blacks in western popular culture. New Haven: Yale University Press.

Peters, Erica. 2004. Indigestible Indochina: attempts to introduce Vietnamese food into France in the inter-war period. In Empire and Culture: the French experience, 1930-1940, ed. Martin Evans. New York: Palgrave.

PORTER, Bernard. 2006. The Absent-Minded Imperialists: Empire, society, and culture in Britain. Oxford: Oxford University Press.

ROBERTS, Mary Louise. 1994. A Civilization without Sexes: reconstructing gender in postwar France, 1917-1927. Chicago: University of Chicago Press.

Rosaldo, Michelle. 1980. The use and abuse of anthropology: reflections on feminism and cross-cultural understanding. Signs 5(3): 389-417.

Rose, Jacqueline. 1996. States of Fantasy. Oxford: Oxford University Press.

SCHNEIDER, William. 1982. An Empire for the Masses: the French popular image of Africa, 1870-1900. Westport: Greenwood Press.

SCOTT, Joan. 1986. Gender: a useful category of historical analysis. American Historical Review 91(5): 1053-1075.

— 1991. The evidence of experience. Critical Inquiry 17(4): 773-797.

STOVALL, Tyler. 2003. National identity and shifting imperial frontiers: whiteness and the exclusion of colonial labor after World War I. Representations 84: 52-72.

Terrio, Susan. 2000. Crafting the Culture and History of French Chocolate. Berkeley: University of California Press.

THOMPSON Andrew. 2005. The Empire Strikes Back? the impact of imperialism on Britain from the mid-nineteenth century. Harlow and New York: Pearson Longman.

Wilson, Katherine, ed. 2004. A New Imperial History: culture, identity, and modernity in Britain and the Empire, 1660-1840. Cambridge: Cambridge University Press. 